\title{
Effects of NAA on the Occurrence of Hollow Root in the Japanese Radish (Raphanus sativus L. cv. Gensuke)
}

\author{
Yasutaka Kano and Nobuyuki Fukuoka \\ Ishikawa Agricultural College, Nonoichi, Ishikawa 921
}

\begin{abstract}
Summary
Hollowing in the root of Japanese radish (Raphanus sativus L.), a physiological disorder characterized by the lengthwise cleavage of the central stele, has been frequently associated with summer-sown crops. In this study, the involvement of auxin in the occurrence of hollow root in 'Gensuke' radish was investigated by spraying the leaves with a synthetic auxin, NAA, ( $\alpha$-naphthaleneacetic acid) of various concentrations at different growth periods.

Daily foliar applications of NAA for 15 days during four different periods revealed that $10 \mathrm{mg} \cdot$ liter $^{-1}$ NAA applied between 16 and 30 days after sowing markedly suppressed root thickening and promoted the development of hollow roots. Treatments with NAA after this period produced little or no effect, especially at 0.1 and $1 \mathrm{mg} \cdot$ liter $^{-1}$. Investigation of the effects of NAA on root morphology and the development of hollowing in roots revealed that spraying with NAA from the time seedlings emerge to 30 days after sowing caused roots to form densely arranged xylem vessels, indicating a decrease in the meristematic activity of xylem parenchymatous cells.

The evidence leads us to conclude that the high occurrence of hollow root in plants treated with $10 \mathrm{mg} \cdot$ liter $^{-1} \mathrm{NAA}$ results from the lowering of meristematic activity in xylem parenchymatous cells among vessels because the cells lignify. This leads to small roots with densely arranged vessels and suppression of proliferation of "large parenchymatous cells" which usually project from the internal surface of the air space. Consequently, the intercellular air spaces coalesce into a large hollow cavity as the root continues to thicken.
\end{abstract}

\section{Introduction}

The Japanese radish cv. Gensuke has been largely cultivated in Ishikawa Prefecture for its flavour. When sown in July, however, it often develops a longitudinal hollow gap in the central stele, thus lowering the quality of the root. The occurrence of hollow root depends upon soil temperature (Kano, 1987, 1989a), planting density (Kano and Fukuoka, 1991), and cultivars (Kano, 1989b; Kano and Fukuoka, 1989, 1990; Kano et al., 1991).

Intercellular air spaces in the central stele of the 'Gensuke' root grow into a hollow cavity when air spaces fail to be filled with "large parenchymatous cells" (Kano, 1989b; Kano and Fukuoka, 1989). Walls of cells surrounding the cavity in the hollow

Received for publication 15 March 1991. This work was partly supported by a Grant-in-Aid for Scientific Research (C) No.62560035 from Ministry of Education, Science and Culture. root of Raphanus sativus L. undergo lignification (Watanabe, 1959). Intercellular air spaces often coalesce into a longitudinal hollow gap under high soil temperatures because cells abutting the air space lignify rather than dividing and preventing the cavity from forming (Kano et al., 1992a; Kano and Fukuoka, 1992).

Hayward (1951) described how vascular bundles are separated from one another by the continued division and growth of xylem parenchymatous cells. Vessels in a normal root become sparse as the root grows (Kano and Fukuoka, 1991), but under exposure to high soil temperatures they become dense because the parenchymatous cells either fail to divide through lignification or they divide slowly (Kano et al., 1992a). Therefore, we speculate that the occurrence of hollow root and arrangement of vessels are closely related to the proliferation of xylem parenchymatous cells.

The lignification of cells in plant tissues is ac- 
celerated by auxin treatment (Jacobs and Morrow, 1957; Koblitz, 1964; Thimann and O'Brien, 1965). Kano and Shigematsu (1988) traced the close relationship between the occurrence of hollow root and NAA foliar application in cv. Gensuke.

We conclude that auxin plays an important role in the arrangement of vessels and development of hollow gap. In this paper, we discuss the effects of NAA on the occurrence of hollow root and the way vessels become distributed in the root.

\section{Materials and Methods}

Three experiments were carried out at the Experimental Farm of Ishikawa Agricultural College.

\section{Effect of the time of NAA treatment on the occur- rence of hollow root}

Seeds of cv. Gensuke were sown on 28 July 1987. The plants were divided into 5 plots. Solutions of $10 \mathrm{mg} \cdot$ liter $^{-1}$ of NAA with $0.1 \%$ Tween 20 were foliar-sprayed once everyday for 15 consecutive days to each of 4 plots during different growth periods; from the time seedlings emerged to the 15th day (Plot 1), from the 16th to the 30th day (Plot 2), from the 31st to the 45th day (Plot 3 ), and from the 46th to the 60th day (Plot 4). The remaining group was given no treatment and designated as control (Plot 5). The amounts of fertilizers and the times they were given are described elsewhere (Kano, 1987). On the 60th day after sowing, 20 plants were sampled randomly from each group; 10 uniform roots were selected and determined for their fresh weights and hollow indices. In the latter determination, the root was cut lengthwise along the central axis, and the maximum width and length of the hollow were measured. A root whose hollow index ([the maximum hollow width] $\times$ [the maximum hollow length]) exceeded $100 \mathrm{~mm}^{2}$ was regarded as a hollow root.

\section{Effect of NAA concentration on the occurrence of hollow root}

Seeds of cv. Gensuke were sown on 12 July 1989. Three groups of plants were sprayed evenly with solutions of $0.1,1.0$ and $10 \mathrm{mg} \cdot 1$ iter ${ }^{-1}$ of NAA with $0.1 \%$ Tween 20 on the 20th, 23rd, 26th, 32nd and 35th day. Fifteen plants were sampled from each group at the end of each stage to weigh the root and evaluate the occurrence and size of hollows. A root whose hollow index exceed- ed $100 \mathrm{~mm}^{2}$ was regarded as a hollow root.

\section{Effect of the time of NAA treatment on vessel ar- rangement in the root}

Seeds of 'Gensuke' were sown on 20 July 1989. The plants were divided into three groups, one was sprayed evenly with a solution of $10 \mathrm{mg} \cdot$ liter $^{-1}$ of NAA with $0.1 \%$ Tween 20 once everyday from the time seedlings emerged to the 30 th day (early treatment), another from the 31st day to the 60 th day (late treatment), and the third group was not sprayed (control). On the 30th and 60 th day after sowing, 20 plants were sampled from each group and 10 uniform roots were selected to determine their fresh weight and hollow indices. In this case, a root whose hollow index exceeded $50 \mathrm{~mm}^{2}$ was regarded as a hollow root because of general smallness of hollows. Vessel arrangement was determined as follows. First, the central and outer regions of the mid-portion of 30 . and 60-day old roots were dehydrated, embedded in paraffin, and then cut transversely into $10 \mu \mathrm{m}$ sections. One group of the sections was stained with hematoxylin and eosin solutions and another group was treated with phloroglucinol-HCl reagent (Migita and Ojio, 1969) which stains lignin red. A group of sections of the outer region of the 30-day old root was not examined in this case. To observe the arrangement of vessels in the cross section of roots, a 5-mm slice taken from the mid-portion of the root was treated with phloroglucinol-HCl reagent for $10 \mathrm{~min}$. After taking photographs of the magnified cross sections, the spots dyed in red were traced on paper.

\section{Results}

\section{Effect of the time of NAA treatment on the occur- rence of hollow root}

Plot 2 produced smallest roots, whereas the control and Plot 1 produced the largest ones (Fig. 1). There were significant differences between the occurrence of hollow root in Plot 2 and those of the control and Plot 4 (Table 1). Roots with the largest cavity and highest frequency occurred in Plot 2 (Table 2). The control, Plot 1 and Plot 4 produced hollow roots with a hollow index of less than $200 \mathrm{~mm}^{2}$, whereas those in Plot 2 had a hollow index which was five-fold greater-1,094 $\mathrm{mm}^{2}$. 


\section{Effect of NAA concentration on the occurrence of hollow root}

At the 60-day old stage, the heaviest root resulted from the $1 \mathrm{mg} \cdot$ liter $^{-1} \mathrm{NAA}$ treatment, whereas the lightest resulted from the $10 \mathrm{mg} \cdot$ liter $^{-1} \mathrm{NAA}$ (Table 3). At the 45-day old stage, the number of hollow root of $10 \mathrm{mg} \cdot$ liter $^{-1}$ treatment was significantly different from those of the control and of $0.1 \mathrm{mg} \cdot \mathrm{liter}^{-1}$ treatment (Table 4); the total number of hollow roots in the $10 \mathrm{mg} \cdot$ liter $^{-1}$ treatment was greatest. The size of the hollow grew as the roots thickened (Table 5) so that the hollow index on the 60th day after sowing as well as the sum of the hollow index, measured on the 15th, 30th, 45th and 60th days after sowing, increased as the concentration of NAA increased. At the 60-day old stage, the hollow index of $10 \mathrm{mg} \cdot \mathrm{liter}^{-1}$ treatment

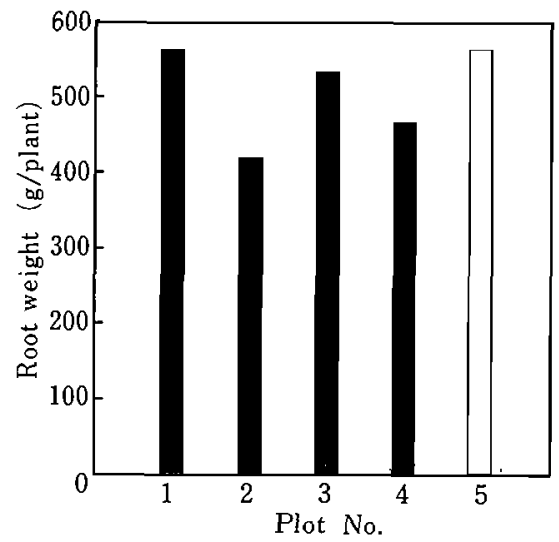

Fig. 1. Effect of the time of NAA treatment on root growth. Plot 1: treatment from the time seedlings emerge to the 15th day. Plot 2: from the 16 th to the 30th day. Plot 3: from the 31 st to 45 th day. Plot 4 : from the 46 th to 60 th day. Plot 5 : no treatment was given. was significantly different from those of the control and $0.1 \mathrm{mg} \cdot$ liter $^{-1}$ treatment.

\section{Effect of the time of NAA treatment on vessel ar- rangement in the root}

The root weight ( $45.5 \mathrm{~g}) 30$ days after sowing was nearly half as large as that of the control $(91.2 \mathrm{~g})$. Sixty days after sowing, the root weights of the early-, late treatment, and control were 510 , 569 , and $787 \mathrm{~g}$, respectively. No hollow roots was observed 30 days after sowing in all plots except in the early NAA treatment which had 3 roots with a mean hollow index of $105 \mathrm{~mm}^{2}$. Sixty days after sowing, roots of from the early- and late-

Table 1. Effect of the time of NAA treatment on the occurrence of hollow root.

\begin{tabular}{cc}
\hline Time of NAA treatment & Occurrence of hollow root \\
(Days after sowing/plot No.) & 60 days after sowing (\%) \\
\hline $1-15 / 1$ & $40 \mathrm{ab}^{2}$ \\
$16-30 / 2$ & $70 \mathrm{a}$ \\
$31-45 / 3$ & $40 \mathrm{ab}$ \\
$46-60 / 4$ & $10 \mathrm{~b}$ \\
Control / 5 & $20 \mathrm{~b}$ \\
\hline
\end{tabular}

"Means within a column by the same letter are not significantly different at the $5 \%$ level (Duncan's multiple range test).

Table 2. Effect of the time of NAA treatment on hollow index in the root.

\begin{tabular}{cc}
\hline \hline $\begin{array}{c}\text { Time of NAA treatment } \\
\text { (Days after sowing/plot No.) }\end{array}$ & $\begin{array}{l}\text { Hollow index } 60 \text { days } \\
\text { after sowing }\left(\mathrm{mm}^{2}\right)\end{array}$ \\
\hline $1-15 / 1$ & $161 \mathrm{~b}^{2}$ \\
$16-30 / 2$ & $1,094 \mathrm{a}$ \\
$31-45 / 3$ & $337 \mathrm{~b}$ \\
$46-60 / 4$ & $110 \mathrm{~b}$ \\
Control / 5 & $186 \mathrm{~b}$
\end{tabular}

${ }^{z}$ Means within a column by the same letter are not significantly different at the $5 \%$ level (Duncan's multiple range test).

Table 3. Effect of NAA concentration on root weight (g).

\begin{tabular}{ccccc}
\hline \multirow{2}{*}{$\begin{array}{c}\text { NAA conc. } \\
\left(\mathrm{mg} \cdot \text { liter }^{-1}\right)\end{array}$} & \multicolumn{4}{c}{ Days after sowing } \\
\cline { 2 - 5 } & 15 & 30 & 45 & 60 \\
\hline 0 & $0.5 \mathrm{a}^{2}$ & $55.3 \mathrm{ab}$ & $318 \mathrm{bc}$ & $758 \mathrm{ab}$ \\
0.1 & $0.5 \mathrm{a}$ & $60.8 \mathrm{a}$ & $388 \mathrm{a}$ & $860 \mathrm{ab}$ \\
1 & $0.5 \mathrm{a}$ & $46.2 \mathrm{~b}$ & $363 \mathrm{ab}$ & $890 \mathrm{a}$ \\
10 & $0.4 \mathrm{a}$ & $57.9 \mathrm{ab}$ & $265 \mathrm{c}$ & $669 \mathrm{~b}$ \\
\hline
\end{tabular}

\footnotetext{
${ }^{2}$ Means within a column by the same letter are not significantly different at the $5 \%$ level (Dun-
} can's multiple range test). 
Table 4. Effect of NAA concentration on the number of hollow root.

\begin{tabular}{|c|c|c|c|c|c|}
\hline \multirow{2}{*}{ 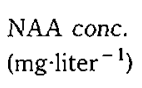 } & \multirow[b]{2}{*}{15} & \multicolumn{3}{|c|}{ Days after sowing } & \multirow{2}{*}{ Sum } \\
\hline & & 30 & 45 & 60 & \\
\hline 0 & $0 \mathrm{a}^{z}$ & $9 \mathrm{ab}$ & $5 c$ & $9 \mathrm{ab}$ & 23 \\
\hline 0.1 & $0 \mathrm{a}$ & $6 \mathrm{~b}$ & $8 \mathrm{bc}$ & $7 \mathrm{~b}$ & 21 \\
\hline 1 & $0 \mathrm{a}$ & $4 \mathrm{~b}$ & $10 \mathrm{~b}$ & $12 \mathrm{ab}$ & 26 \\
\hline 10 & $0 \mathrm{a}$ & $13 \mathrm{a}$ & $15 \mathrm{a}$ & $14 \mathrm{a}$ & 42 \\
\hline
\end{tabular}

"Means within a column by the same letter are not significantly different at the $5 \%$ level (Duncan's multiple range test).

Table 5. Effect of NAA concentration on hollow index $\left(\mathrm{mm}^{2}\right)$ in the root.

\begin{tabular}{|c|c|c|c|c|c|}
\hline \multirow{2}{*}{$\begin{array}{l}\text { NAA conc. } \\
\left.\text { (mg liter }{ }^{-1}\right)\end{array}$} & \multicolumn{4}{|c|}{ Days after sowing } & \multirow{2}{*}{ Sum } \\
\hline & 15 & 30 & 45 & 60 & \\
\hline 0 & $0 a^{2}$ & $365 \mathrm{~b}$ & $115 \mathrm{c}$ & $887 \mathrm{~b}$ & 1,367 \\
\hline 0.1 & $0 \mathrm{a}$ & $119 \mathrm{c}$ & $537 \mathrm{c}$ & $900 \mathrm{~b}$ & 1,556 \\
\hline 1 & $0 \mathrm{a}$ & $81 \mathrm{c}$ & $1,751 \mathrm{~b}$ & $2,635 \mathrm{ab}$ & 4,467 \\
\hline 10 & $0 \mathrm{a}$ & $658 \mathrm{a}$ & $3,178 \mathrm{a}$ & $3,306 \mathrm{a}$ & 7,142 \\
\hline
\end{tabular}

treatment has a hollow index of 1,214 and $60 \mathrm{~mm}^{2}$, respectively; the control roots exhibited no cavity.

Cells surrounding vessels were dyed dark blue with hematoxylin (Figs. 2 and 3); the dark blue spots were located almost in the same places as the red spots dyed with phloroglucinol- $\mathrm{HCl}$ reagent (Figs. 2 and 3). Comparison of the result of staining the tissues with hematoxylin with that of staining with phloroglucinol- $\mathrm{HCl}$ reagent revealed that the red spots dyed with phloroglucinol- $\mathrm{HCl}$ reagent coincided with the locations of lignified vessels. The density of vessel arrangement in a given area of the 30-day old root in the control was low both in the central and outer regions due to large spaces between the vessels, but the density was high in the early treatment due to small spaces between vessels (Fig. 2). Therefore, the overall arrangement of vessels in the root was much tighter in the early treatment (Fig. $2-\mathrm{H}$ ) than in the control (Fig. 2-G). In 60-day old plants the space between vessels in the central region of the root was the smallest in the early treatment (Fig. 3-B and $\mathrm{E})$, the longest in the control (Fig. 3-A and D), and inbetween in the late treatment (Fig. 3-C and F). On the other hand, in the outer region the space was largest in the control (Fig. 3-G and J), smallest in the late treatment (Fig. 3-I and L), and inter- mediate in the early treatment (Fig. 3-H and K). Consequently, the overall arrangement of vessels in the root was most dense in the early treatment (Fig. 3-N), in contrast to the sparsity in the control (Fig. 3-M). The density of vessel arrangement in the late treatment (Fig. 3-O) was intermediate between that in the control and the early treatment.

\section{Discussion}

Root thickening was remarkably prevented by the foliar treatment with NAA during the early half of the growing period. Rapid thickening begins at around the 20th day after sowing in $\mathrm{cv}$. Gensuke (Kano, 1987). Kano (1989a) pointed out that the growth of 'Gensuke' root was greatly inhibited by high soil temperature during 16 to 30 days after sowing. It seems that the rapid thickening root is vulnerable to adverse environmental conditions.

Synthetic auxins such as 2,4-D moves rapidly to the root tip when applied to cotyledons or leaves of Gossypium indicum Lam. and Cucumis sativus L. (Crafts, 1956). Morris et al. (1969) showed that radioactivity associated with ${ }^{14} \mathrm{C}$-labeled IAA applied to the shoot tip was transported rapidly into the root system in pea seedlings. Assuming that NAA applied to leaves of 'Gensuke' certainly moves into the root, a rise of auxin concentration 


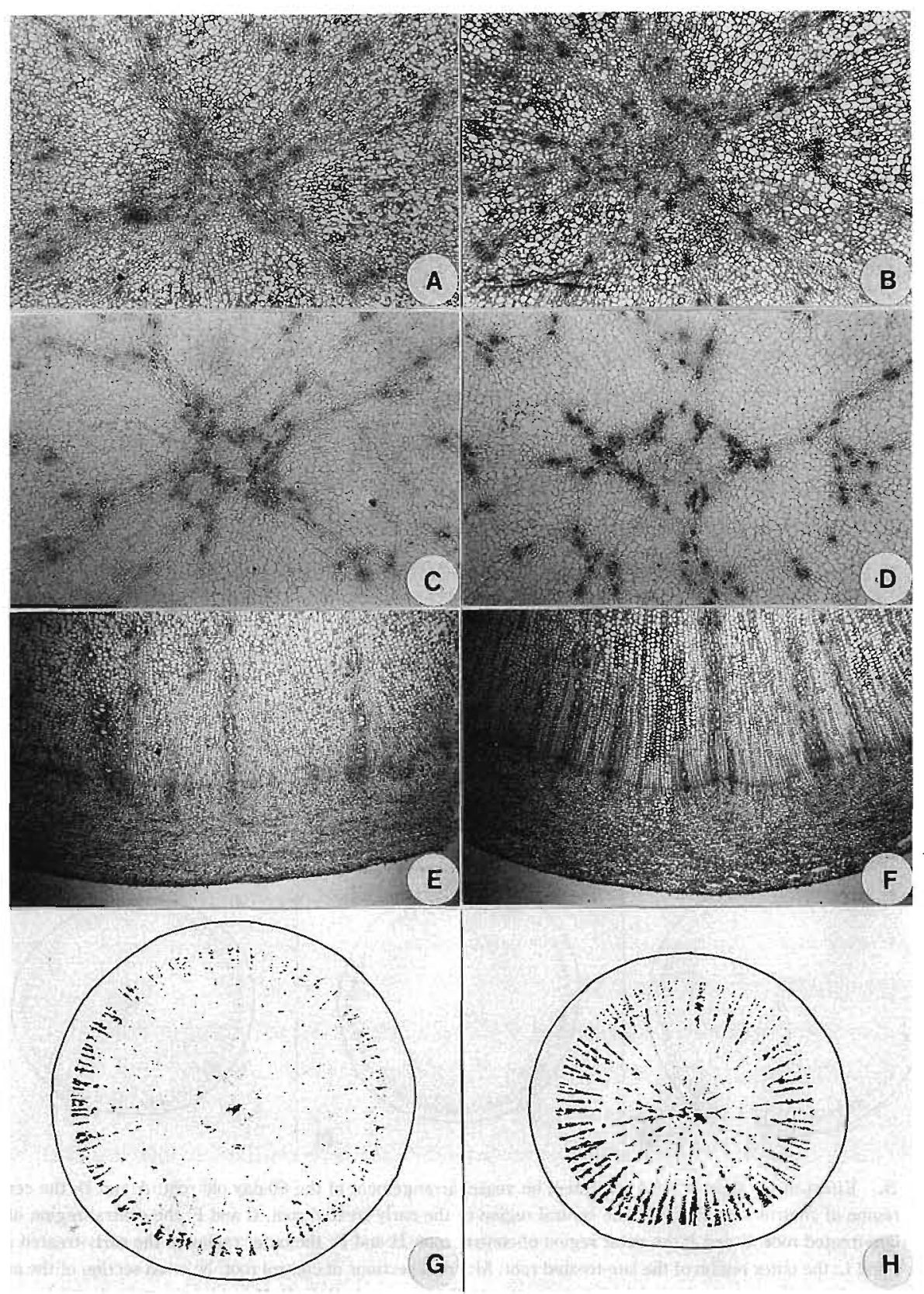

Fig. 2. Effect of the time on NAA treatment on vessel arrangement of the 30-day old root. A and C: the central region of control root. $\mathrm{B}$ and $\mathrm{D}$ : the central region of the early-treated root. $\mathrm{E}$ : the outer region of control root. F: the outer region of the early-treated root. G: cross section of control root. H: cross section of the early-treated root. Sections of $\mathrm{A}, \mathrm{B}, \mathrm{E}$ and $\mathrm{F}$ were stained with hematoxylin and eosin solution. Sections of $\mathrm{C}, \mathrm{D}, \mathrm{G}$ and $\mathrm{H}$ were stained with phloroglucinol- $\mathrm{HCl}$ reagent, and the spots dyed red in $G$ and $H$ were traced on paper. 


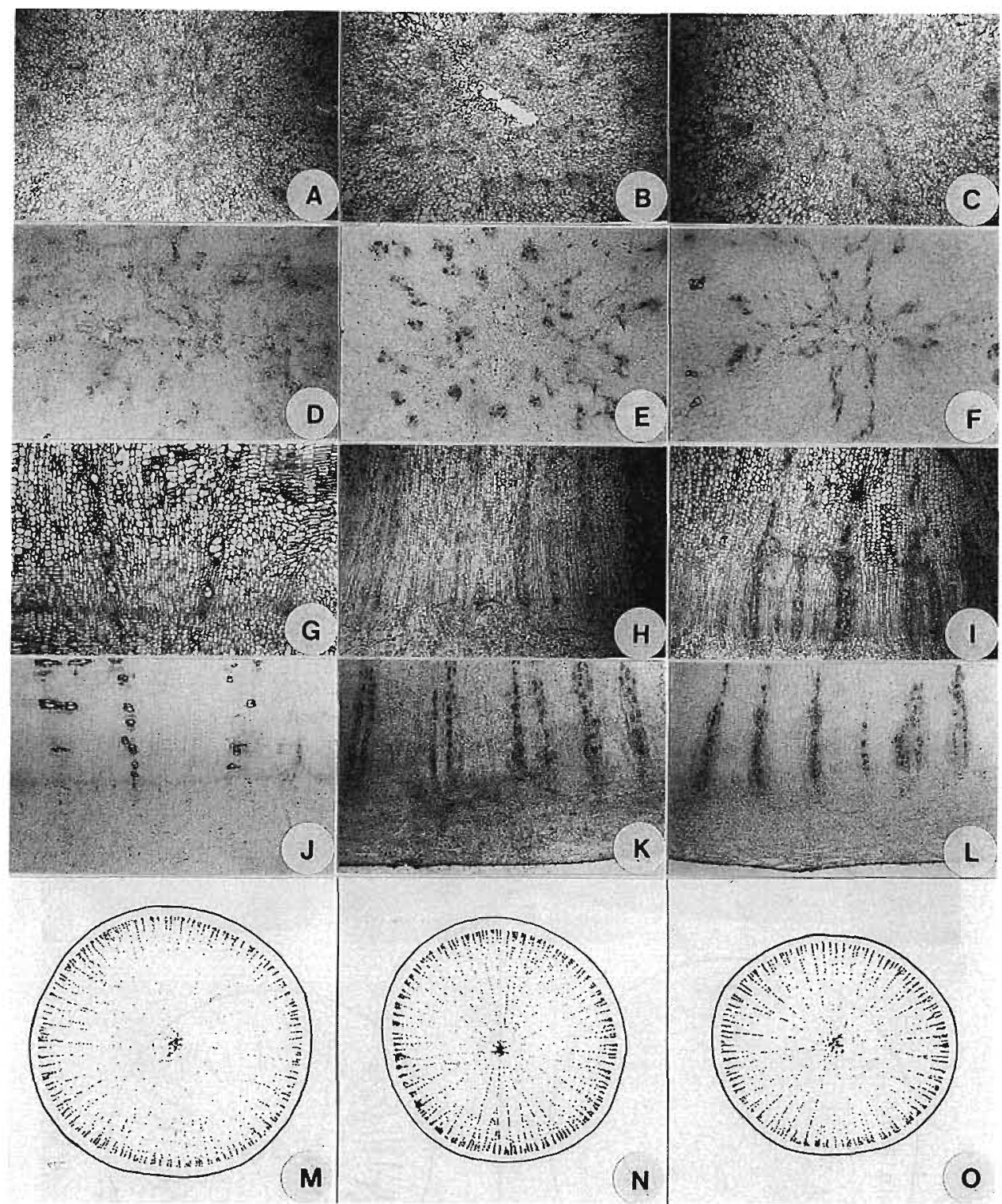

Fig. 3. Effect of the time of NAA treatment on vessel arrangement of the 60-day old root. A and D: the central region of control root. $\mathrm{B}$ and $\mathbf{E}$ : the central region of the early-treated root. $\mathrm{C}$ and $\mathrm{F}$ : the central region of the late-treated root. $\mathrm{G}$ and $\mathrm{J}$ : the outer region of control root. $\mathrm{H}$ and $\mathrm{K}$ : the outer ragion of the early-treated root. $I$ and L: the outer region of the late-treated root. M: cross sections of control root. N: cross section of the early. treated root. O: cross section of the late-treated root. Sections of A, B, C, G, H and I were stained with hematoxylin and eosin solution. Sections of D, E, F, J, K, L, M, N and O were stained with phloroglucinol-HCl reagent and the spots dyed red in $\mathrm{M}, \mathrm{N}$ and $\mathrm{O}$ were traced on paper.

in the root of NAA-treated plant is expected. The density of vessel arrangement in the central region of the root was high in the early NAA treatment but not in the outer region in the late NAA treat- ment. The root of Japanese radish thickens while xylem parenchymatous cells divide and grow, and vessels estranged widely from one another in radial direction (Hayward, 1951; Kano, 1989c; Kano and 
Fukuoka, 1991). Lignification of cells in plant tissues is accelerated by auxin treatment (Jacobs and Morrow, 1957; Koblitz, 1964; Thimann and O’Brien, 1965). Kano et al. (1992) demonstrated that the lignification of xylem parenchymatous cell wall of Raphanus sativus L. root was promoted by NAA applied to leaves. Lignified cells can neither divide (Schellenberg, 1896) nor enlarge (Warburg, 1893). We conclude that the dense arrangement of vessels in the root results from the NAA treatment which strongly inhibits meristematic activity of xylem parenchymatous cells. The dense arrangement in the outer region of the root in the late NAA treatment is caused by the suppression of cell division of secondary cambia which develop outside of the central region (Hayward, 1951).

The occurrence of hollow root was high in the early treatment. High soil temperature during the 16 th to the 30th day after sowing causes the highest occurrence of hollow root in cv. Gensuke (Kano, 1989a) and the active lignification in cells surrounding the intercellular air space in the central stele of the root (Kano et al., 1992a). In normal 'Gensuke' roots, "large parenchymatous cells" grow to occupy the intercellular air space (Kano, 1989c) but in those forming a cavity, they lignify and do not intrude into the air space (Kano and Fukuoka, 1992). Kano et al. (1992b) revealed that in several cultivars of Japanese radish, NAA foliar application caused the active lignification at the cells surrounding the air space. This phenomenon lead us to conclude that the early NAA treatment prevents the large cellular elements from proliferating and filling the intercellular air space, resulting in hollowness. On the contrary, late NAA treatment caused no such phenomenon. A most reasonable cause for this is that intercellular air space had already been filled with large parenchymatous cells prior to the NAA application.

By establishing a close relationship between high occurrence of hollow roots and a treatment with NAA early in the growing period, we reason that NAA inhibits cell division and enlargement of the xylem parenchymatous cells, especially those between vessels, by inducing lignin formation. Consequently, the root, having compact cells and densely arranged vessels, thickens, but the lignification of cells lining the space prevents large cellular elements from intruding into the intercellular air space. This allows the air spaces to coalesce and combine into a large, hollow, central cavity as roots continue to expand radially and elongate.

\section{Literature Cited.}

Crafts, A.S. 1956. The mechanism of transportation: methods of study with ${ }^{14} \mathrm{C}$-labeled 2,4-D. Hilgardia $26: 287-334$.

Hayward, H.E. 1951. Cruciferae. Raphanus sativus. p.283-308. In: The structure of economic plants. The Macmillan Company, New York.

Jacobs, W.P. and I.B. Morrow. 1957. A quantitative study of xylem development in the vegetative shoot apex of Coleus. Amer. J. Bot. 44:823-842.

Kano, Y. 1987. Roles of temperature in the occurrence of hollow root in Japanese radish cv. Gensuke. J. Japan. Soc. Hort. Sci. $56: 321-327$.

Kano, Y. 1989a. Effect of time of high and low temperature treatments on the growth of Japanese radish cv. Gensuke and the occurrence of hollow root. J. Japan. Soc. Hort. Sci. 57:626-632.

Kano, Y. 1989b. Effects of growth-especially of the growth of the central part of the root-on the occurrence of hollow root in Japanese radishes. Bull. Ishikawa Agr. Coll. $19: 17-23$.

Kano, Y. 1989c. Development of hollow in the root of a Japanese radish, cv. Gensuke grown at different soil temperatures. Bull. Ishikawa Agr. Coll. $19: 24-34$.

Kano, Y. and T. Shigematsu. 1988. Studies on the occurrence of hollow root in Japanese radish cv. Gensuke. 6. Effects of plant growth regulators on root growth and the occurrence of hollow root. Abstr. Japan. Soc. Hort. Sci. Autumn Meet. : 394-395. (In Japanese).

Kano, Y. and N. Fukuoka. 1989. Relationship between the occurrence of hollow root and the root growth, endogenous cytokinin activity in the root of Japanese radishes. Bull. Ishikawa Agr. Coll. $19: 35-42$.

Kano, Y. and N. Fukuoka. 1990. Studies on the occurrence of hollow root in Japanese radish cv. Gensuke. 9. Comparison of the occurrence of hollow root in several cultivars. J. Japan. Soc. Hort. Sci. 59 (Suppl. 1) : 342-343. (In Japanese).

Kano, Y. and N. Fukuoka. 1991. Effect of planting density on the occurrence of hollow root of cv. Gensuke. J. Japan. Soc. Hort. Sci. $60: 379-386$.

Kano, Y., C. Kuse and M. Ueda. 1991. Comparison of vessel-density in the root and the occurrence of hollow roots among Japanese radishes. J. Japan. Soc. Hort. Sci. 60 (Suppl. 1) : 624. (In Japanese).

Kano, Y., N. Fukuoka, T. Kamei, K. Kondo, C. Seto and S. Tsuchida. 1992a. Studies on the occurrence of hollow root in Japanese radish cv. Gensuke. 15. Effect of the time of heating on the lignification of 
cells in the central region of root. J. Japan Soc. Hort. Sci. 61 (Suppl. 1) : 328-329. (In Japanese).

Kano, Y., N. Fukuoka, T. Kamei, K. Kondo, C. Seto and S. Tsuchida. 1992b. Studies on the occurrence of hollow root in Japanese radish cv. Gensuke. 16. Comparison of the lignification of cells in the central region of root among cultivars by auxin treatment. J. Japan. Soc. Hort. Sci. 61 (Suppl. 1) : 330-331. (In Japanese).

Kano, Y. and N. Fukuoka. 1992. Relationship between the occurrence of hollowing and lignification of parenchymatous cells in the root of Japanese radish cv. Gensuke. J. Japan. Soc. Hort. Sci. $61: 359-366$.

Koblitz, H. 1964. Chemisch-physiologische Untersuchungen an pflanzlichen Zellwänden. Flora 154 : 511-546.

Migita, T. and G. Ojio. 1969. Phloroglucinol reaction. p.161. Editorial Committee of Encyclopaedia Chim- ica (eds.). Encyclopaedia Chimica. Vol.8. (In Japanese).

Morris, D.A., R.E. Briant and P.G. Thomson. 1969. The transport and metabolism of ${ }^{14} \mathrm{C}$-labelled indoleacetic acid in intact pea seedlings. Planta 89 : 178-197.

Schellenberg, H. 1896. Beitäge zur Kenntnis der verholzten Membranen. Jahrb. Wiss. Bot. $29: 237-266$.

Thimann, K.W. and T.P. O'Brien. $1965 . \quad$ Histological studies on the coleoptiles. II. Comparative vascular anatomy of coleoptiles of Avena and Triticum. Amer. J. Bot. 52 : 918-923.

Warburg, O. 1893. Ueber den Einfluss der Verholzung auf die Lebensvorgänge des Zellinhaltes. Ber. Deut. Bot. Ges. 11: 425-441.

Watanabe, K. 1959. A note on the internal callus formation in radish roots. Bot. Mag. $72: 409-412$.

源助ダイコンの空洞発生に及ぼす NAA 処理の影響

加納恭卓 - 福岡信之

石川県農業短期大学 921 石川県石川郡野々市町

\begin{abstract}
摘
源助ダイコンの根部における道管配列および空洞の 発達に及ぼすオーキンの作用機作を明らかにするため, NAA (ナフタレン酢酸) のナトリウム塩水溶液の葉面 散布を試みた。

出芽後から播種後30日目までと播種後31日から60日 目までの各生育期間, 1 日に 1 回 NAA の10mg・liter ${ }^{-1}$ 溶液を処理したところ，前者の場合に根重が著しく抑 制され，空洞の発達が促進された。导らに，播種から 収穫までの 60 日間を，15日間ごとにわけた四つの各生 育期間 1 日に 1 回 $10 \mathrm{mg} \cdot$ liter $^{-1} の \mathrm{NAA}$ 溶液を処理し たところ，播種後16日目から 30 日目までの間処理した もので最も根重が小さくなり，空洞は最も発達したが, それ以外の処理区ではほとんどNAAの影響は認めら れなかった。 また，NAAの処理濃度についてみると，

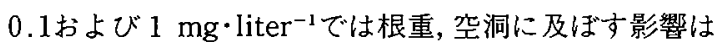

\section{要}

まったく認められなかった、根部における道管配列に 及ぼす NAAの影響についてみたところ, NAAの10mg・ liter ${ }^{-1}$ を出芽後から播種後30日目まで処理した区で, 根 部の生育の著しい抑制と，空洞の発達が最も顕著とな ク，根部の道管配列は最も密となった。

これらの結果より，源助多コンの空洞発達におけ るNAAの作用機作について次のように考えることが できる、NAAを葉面散布すると根部におけるオーキシ ンレベルが高くなり，その結果，木部柔細胞の木化が 促進される。杹すると柔細胞の分裂活性が低下し， 根重は小さくなり道管配列は密となる。 また, 根部中 心部に形成される細胞間隙の周辺の采細胞も木化して しまうため，間陌を充填していく“大型の柔細胞”が 增生されなくなり間隙は空洞へと発達する。 